\title{
Üniversite Sınavına Hazırlanan ve Özel Dershanelere Devam Eden Lise Son Sınıf Öğrencilerinin Kendilerinde Algıladıkları Ego Durumları ile Sinav Kaygı Düzeyleri Arasındaki İlişkinin İncelenmesi
}

\author{
DOI: 10.26466/opus.522188
}

*

\author{
Sabahattin Şerif Meşe* - $\underline{\text { Halis Özerk }}{ }^{* *}$ \\ * Uzm. Psikolog, İstanbul Arel Üniversitesi, Psikoloji Yük. Lisans Programı. Sefaköy İstanbul. \\ E-Posta: sabahattinserif@gmail.com ORCID: 0000-0002-5553-4005 \\ ** Dr. Öğr. Üyesi, İstanbul Arel Üniv. Sosyal Bilimler Enstitüsü, Sefaköy, İstanbul \\ E-Posta: halisozerk@halisozerk.com ORCID: $\underline{0000-0001-5530-6638}$
}

$\ddot{O} z$

Bu araştırmanın amacl; üniversite sınavlarına (YGS ve LYS) hazırlanan lise 12.sını öğrencilerinin kendilerinde algıladıkları ego durumları ile sınav kaygısı düzeyleri arasındaki ilişkiyi incelemektir. Çalışma grubu, 2014-2015 öğretim yılında Ankara İli Çankaya ilçesindeki Millî Eğitim Bakanlığı'na bağlı altı (6) resmi Anadolu lisesinde öğrenim gören ve lise son sinıfta olan toplam 535 (Kız=307; Erkek= 228) öğrenciden oluşmaktadır. Çalışma grubundaki öğrencilerin yaş aralı̆̆ı 16-19 arasında değişmektedir. Araştırmanın değiş̧kenlerinden olan ego durumlart ile ilgili veriler, Ego Durum Ölçeği (Arn, 1989) aracılığılyla, diğger değişken olan sınav kaygısı ise Sınav Kaygısı Ölçeği (Öner, 1990) kullanılarak elde edilmiştir. Ayrıca öğrencilere ilişkin demografik bilgiler, araştırmacı tarafından oluşturulan Kişisel Bilgi Formu kullanılarak toplanmıştır. Araştırmanın sonuçlarına göre, lise 12. Sinıftaki öğrencilerin (hem kız hem erkek öğrencilerin) sinav kaygı düzeylerinin ortalamanın üzerinde olduğu görülmüştür. Kız öğrencilerin sinav kaygılarının ise gerek tümtest puanları bakımından gerekse testin alt boyutlar (kuruntu ve duyuşsal) bakımından erkeklerinkinden anlaml olarak daha yüksek bulunmuştur. Ego durumlar bakımından ise, öğrencilerin en fazla Koruyucu Ebeveyn (KE) ego durumunda (\%48, ikinci olarak da Doğal Çocuk (DÇ) ego durumunda (\%30) en az olarak da Eleştirel Ebeveyn (EE) ego durumunda (\%4) ve Uygulu Çocuk (UÇ) ego durumunda (\%6) kendilerini algzladıkları görülmektedir. Ego durumlarıyla sınav kaygısı arasındaki ilişki bakımından ise, sadece Yetişkin Ego durumu ile Sınav Kaygisı ölçeğinin alt boyutu olan kuruntu boyutu arasında az da olsa anlaml ilişki olduğu görülmüştür. Transaksiyonel Analiz kuramı çerçevesinde enerji yoğunluğunun ego durumlarına göre dağılımında, enerjinin en yüksek düzeyde Koruyucu Ebeveyn ego durumunda kullanıldı̆̆ görülmüştür. Bulgular ilgili literatüre dayanılarak tartışılmış, gelecek araştırmalara yönelik öneriler sunulmuştur.

Anahtar Kelimeler: Transaksiyonel Analiz, Ego Durumları, Sınav kaygısı. 


\title{
Investigating The Relationship Between Exam Anxiety Level And Perceived Ego States Of The High School Students That Prepare To Take University Entrance Exams By Going To Private Classroms
}

\begin{abstract}
The purpose of this study was to review the relationship between self-perceived ego states of twelfthgraders who prepare for university entrance exams (YGS (the transition to higher education examination) and LYS (undergraduate placement exam)) and exam anxiety levels. Working group consisted of 535 (Female= 307; Male= 228) high school final year students who study in 6 (six) public Anatolian High School in Çankaya District of Ankara Province in the 2014-2015 academic year. The age range of students in the working group varies between 16 and 19. Data relating to ego states that is one of the variables of research were obtained by Ego State Scale (Arl, 1989); data relating to another variable, exam anxiety were obtained by Exam Anxiety Scale (Öner, 1990). Moreover, demographic information about students was collected by using the Personal Information Form. With reference to research results, the exam anxiety level of twelfth-graders (both female and male students) is above average. Exam anxiety of female students is significantly higher in comparison with male students in terms of both fulltest scores and subdimensions (delusion and affective) of the test. It is seen when looking at ego states that students perceive themselves in Nurturing Parent Ego State most (48\%); students perceive themselves in Natural Child Ego State in the second place (30\%); students perceive themselves in Criticizing Parent Ego State in the third place (4\%); finally, the same students perceive themselves in Adaptive Child Ego State in the fourth place (6\%). About the relation between ego states and exam anxiety; there is seen a leastwise significant relationship between delusion dimension that is the subdimension of Exam Anxiety Scale and Adult Ego State. We can observe when looking at the distribution of energy density based on ego states within the scope of theory of transactional Analysis that Energy is used in Nurturing Parent Ego State at most. Findings were discussed based on literature; there were also offered suggestions toward the next studies.
\end{abstract}

Keywords: Transactional Analysis, Ego States, Exam Anxiety. 


\section{Giriş}

Sınavların, özellikle bir üst okula geçiş (ortaokuldan Anadolu lisesine, liselerden üniversiteye geçiş) sınavlarının öğrenciler için çok önemli süreçler olduğu, bu süreçlerin öğrencilerde kaygıyı artırdığı, oluşan kaygının da öğrencilerin akademik başarısını olumsuz yönde etkilediği ifade edilmektedir (Dündar, Yapıcı ve Topçu, 2008, s.173; Cassady, 2004, s.569; Hanımoğlu., 2011, s.359; Erkan, 1991; Culler ve Holahan, 1980; Donald ve Katz, 1999; Ekşi, 1998; Yıldırım ve Ergene, 2003; Bacanlı ve Sürücü, 2006).

Ülkemizdeki eğitim sisteminin sınav merkezli olması nedeniyle öğrencilerin ilkokuldan itibaren üniversiteye kadarki süreçte kaygılı ve yıpratıcı bir dönem geçirdiklerini belirtilmektedir (Yıldırım, 2008; Çiçek, 2018).

Sınav kaygısının, benlik saygısı, ebeveyn tutumları, öğrencilerin karar verme stilleri, sınırlılık algı şemaları, güdülenme ve çalışma alışkanlıkları ile ilişkilerini inceleyen çok sayıda çalışma da mevcuttur. Bu çalışmalara aşağıda yer verilmiştir.

Freud, organizmanın kendini tehlikede bulduğu her durumda kayg1nın bir tepki olarak ortaya çıktığını söylemiş ve gerçekçi, nevrotik ve ahlaki kaygı olmak üzere üç tür kaygıdan söz etmiştir. (Freud, 1999, s.269, 285). Bu kaygı türlerinin de sırasıyla; gerçekçi kaygının diş dünya ile nevrotik kaygının İd'le ve ahlaksal kaygının da Süper Ego ile ilişkili olduğunu ifade etmiştir (Freud, 1998, s.105).

Öztürk (2011, s.67) ve May (2012, s.145), (Kierkegard, Heideger, Husserl, Sartre, Binswagner, Freud, Goldstein ve Jaspers'in de belirttiği gibi), kaygı kavramının Almanca karşılı̆̆ının "angst" sözcüğü olduğunu ve kökenini Latince "Angustus"tan (dar boğaz) aldığını söylerler. Aynı yazarlar buna ek olarak kaygının dereceleri olduğunu ve bunların hafif tedirginlik, gerginlik duygusu ve paniğe kadar varan yoğunlukta olduğunu, fizyolojik belirtilerinin ise kan basıncının yükselmesi, nabız atışlarının hızlanması, ağız kuruluğu, göz bebeklerinde genişleme, yüzde solukluk avuç içinde terleme, sık işeme ve dışkılama ve kaslarda gerginliğin artması şeklinde gözlemlenebileceğini belirterek bu belirtilerin ağır tablolar halinde görülmesini de kişinin benliğinin ruhsal acı altında ezilmesi olarak tanımlamışlardır. 
Organizma kendini bilinmeyen bir tehlike karşısında hissettiği durumlarda Hipotalamusta yer alan ve yaşamsal öneme sahip olan "kaçma ve "savaş" davranışları uyarılır (Carlson, 2011, s.74).

Freud genel kaygının özel bir durumu olan sınav kaygısı için ise sınav kaygısının kötü hareketlerden dolayı çocuklukta ebeveynler tarafından verilen cezaların silinmeyen anılarına bağlı olduğunu ve bunların da düşlere yansıdığını belirtir (Freud, 2012, s.323-324).

Spielberger, kaygı konusunda geliştirdiği model ile iki temel kaygıdan bahseder. Bunlar, durumluk ve sürekli kaygıdır. Duruma bağlı olarak ortaya çıkan durumluk kaygıda, kişi kendini geçici olarak tehlikede hisseder ve bundan dolayı da kaygı duyduğunu söyler. Fizyolojik olarak da otonom sinir sisteminde meydana gelen uyarılma sonucunda terleme, sararma ve titreme gibi fiziksel belirtiler ortaya çıkar (Spielberger, 1966; Akt. Öner ve Le Compte, 1985, s.1-2). Spielberger ve Vogg ise sınav kaygisının kuruntu ve duyuşsallık olarak adlandırdıkları boyutları olduğunu belirtir (Sarason,1980).

Genel kaygının özel bir durumu olan sınav kaygısının bilişsel alt boyutu olan kuruntu kaygısında kişinin kendisi hakkındaki düşünceleri ve değerlendirmeleri olumsuzdur. Kişi kendisini yetersiz ve başarısız olarak görür. "Ya başaramazsam ya yapamazsam?" düşüncesi kafasında sürekli yer eder bu da sınav esnasında onun dikkatini dağıtır. "Okuduklarımı anlamıyorum, sınavda daldım, kendimi sınava vermiyorum, ben zaten yeteneksiz ve beceriksiz bir insanım" gibi iç konuşmalar kişinin yaşadı̆̆ 1 kuruntulara örnektir (Öner, 1990, s.1).

Çakmak, Şahin ve Demirbaş (2017), 7. ve 8. Sınıf Öğrencilerinin Sınav Kaygısı ve Benlik Saygısı Arasındaki İlişkiyi inceledikleri çalışmada cinsiyet değişkeni bakımından kız öğrencilerin sınav kaygısının erkek öğrencilere kıyasla anlamlı düzeyde ilişki olduğunu, sınav kaygısı ile benlik saygısı arasında negatif yönde anlamlı bir ilişki bulunduğunu bulgulamıştır. Aynı bulguya Ekşi (1998)' nin, “Sınav Kaygısının Üniversite Adayı Ergenlerde İncelenmesi" çalışmasında da rastlanmaktadır.

Çiçek ve Tanhan (2018) yaptıları çalışmada, üniversite sınavına hazırlanan lise son sınıf öğrencilerinin sınav kaygısı düzeyleri ile öğrencilerin kendilerinde algıladıkları sınırlılık algı şemaları arasında anlamlı bir iliş- 
kinin olduğunu, bununla ilintili olarak, dershaneye gidip gitmeme durumu ile sınırlılık şema algısı arasında da anlamlı bir ilişkinin olduğunu ortaya koymuşlardır.

Koçkar, Günay ve Şahnur (2002), ilköğretim 4.ve 5. Sınıf öğrencileri ile yaptıkları çalışmada, toplam sınav kaygısının ve alt ölçek olan kuruntunun akademik başarı ile ilişkili olduğunu bulgulamışlardır.

Sınav kaygısı ile akademik performans arasındaki ilişkiyi inceleyen yabancı kaynaklı çalışmaların çoğunun sonuçlarına göre, sınav kaygısı yüksek bireylerin akademik performanslarının da düşük olduğu görülmüştür. (Cooley ve Spielberger, 1980, Birenbaum ve Nasser, 1994; Hong, 1999; Sullivan,2002; Cassady,2004; Benjamir, 1991; Culler ve Holand, 1980; Cassady ve Johnson,2002; Brown and Mann, 1991; Zeidner, 1991).

Ülkemizde yapılan çalışmalarda da hemen hemen aynı sonuçların elde edildiği görülmektedir (Gündoğdu,1994; Koçkar, Kılıç ve Şener, 2002; Erkan, 1991). Bilişsel-Dikkat kuramina göre de bireyin kendini olumsuz algılamasının, bunu bilişsel olarak tekrar etmesinin kaygıyı ve dolayısıyla başarısızlığı getireceği ifade edilmektedir (Arnkof ve Smith, 1988). Sınav kaygısı ile benlik saygısı, psikolojik problemler ve psikiyatrik semptomlar arasında anlamlı ilişki olduğunu gösteren araştırmalar da mevcuttur (Hambree, 1988; Morris ve diğ. 1981; Neuderth ve diği. 2009; Kessler ve diği. 2006; Ameringen ve diğ. 2010; Kutlu, 2001; Kavakçı, Güler ve Çetinkaya, 2011).

Erdik ve Özpınar (2015)' in üniversite sınavına hazırlanan lise son sınıf öğrencileriyle yaptığı çalışmada öğrencilerin sınav kaygısı ile anne baba tutumları arasındaki ilişkiye bakılmış, otoriter, koruyucu ve ilgisiz tutum ile sınav kaygısı arasında doğrusal yönde anlamlı bir ilişki bulunmuştur.

Yukarıda da sıralandığı üzere, örgün eğitimin çeşitli düzeylerindeki öğrencilerde sınav kaygısının; benlik algısı, anne baba tutumları, öğrenme stilleri, güdülenme, çalışma alışkanlıkları, sınırlılık algı şemaları gibi birçok değişken ile ilişkisinin çalışıldığ görülmüş ancak öğrencilerin kendilerini algıladıkları ego durumları ile ilişkisini ele alan çalışmaya rastlanmamıştır. Çalışmanın amacı bu ilişkiyi incelemektir. 


\subsection{Sinav kaygisi}

Spielberger'e göre, sinav kaygısı formal bir sınav veya değerlendirme durumunda yaşanan, kişide gerginlik yaratarak onun gerçek performansını ortaya koymasını engelleyen duyuşsal, bilişsel ve davranışsal bir duygu durumudur. Kişi, sınav ve değerlendirilme ortamında iki tür kaygı yaşayabilir (Spielberger, 1972; Akt. Y1ldız, 2007, s.9).

1.1.1. Kuruntu kaygısı (KK): Kuruntu kaygısı sınav kaygısının bilişsel boyutu ile ilgilidir, kişinin kendi hakkındaki düşüncelerinin ve değerlendirmelerinin olumsuz olması durumudur. Kişinin kendisini yetersiz ve başarısız olarak görmesidir. Ya başaramazsam düşüncesi kafasında sürekli yer ettiği için sınav esnasında dikkati dağılır (Bacanlı ve Sürücü, 2005, s.8).

1.1.2. Duyuşsal kaygı (DK): Kişinin bedensel tepkileri ile ilgilidir kişide hızlı kalp atışı, mide bulantıları, ateş basması, üşüme, asabiyet ve stres gibi tepkiler gelişir. Kaygı otonom sinir sistemini olumsuz yönde uyarır (Bacanlı ve Sürücü, 2005, s.8).

\subsection{Transaksiyonel analiz (TA)}

Berne, TA'yı "Karşılıklı Davranışsal Çözümleme" olarak tanımlanmıştır (Berne, 1964; Akt. Özerk, 2008, s.7). Karşılıklı Davranışsal Çözümleme en az iki kişi arasında gerçekleşen iletişim sürecinde davranışların karşılıklı çözümlenmesini ifade etmektedir. Berne, bir uyarıcı ve bir tepkiden oluşan birime, transaksiyon (karşılıklı etkileşim işlemi) adını vermektedir (Berne, 1961; Akt. Akkoyun, 2011, s.37).

\subsubsection{Ego durumları (Ego states)}

Berne'e göre Ego Durumları içsel ve dışsal uyarıcıları organize etmeye yarayan üç ruhsal organin (extero-psyche, neo-psyche ve archaeo-psyche) fenomenolojik belirtileri ve aklın farklı durumları, bu durumlara ilişkin 
duygu, düşünce ve davranış örüntüleridir. Bir başka anlatımla, ego durumları kişiliğin varoluşsal fenomenleri ve öznel yaşantıların bir sınıflamasıdır (Akkoyun, 2011, s.14,17).

\subsubsection{Ego durumlarının analizi}

Ego durumları yapısal ve fonksiyonel olmak üzere iki ayrı modelde incelenmektedir. Kişilik psikolojisinin konusu yapısal analizi gerektirirken, iletişim psikolojisinin konusu yapısal analizi gerektirmektedir (Akkoyun, 2011, s.21).

\subsubsection{Yapisal analiz}

Yapısal analiz ego durumlarının içeriği ile ilgilidir, bunlar aşağıda da kısaca özetlendiği gibi Ebeveyn, Yetişkin ve Çocuk Ego durumlarıdır (Akkoyun, 2011, s.18).

Ebeveyn ego durumu (E): Ebeveyn ego durumu, kişinin yaşamında karş1laştığ başta ebeveyn figürleri ve dış kaynaklardan alınan görüş, tutum, değer ve değer yargılarını algılama şeklindeki davranışları içermektedir (Akkoyun; 2011, s.19).

Çocuk ego durumu (Ç): Çocuklukta yaşanan tüm yaşantıları içeren Çocuk Ego durumu kişinin çocukluğunda yasadığı tüm yaşantıları içermektedir. Buradaki çocuk kavramı ile yaşamın başından sonuna kadar her an her zaman temel varlığı korumaya yönelik olan yaşantılar kastedilmektedir. Onun için bu ego durumu, yalnızca çocukluğa ilişkin yaşantılardan oluşmaz. Bir yetişkin tüm yaşamı boyunca varlığını korumak için uyarıcılar almak ve tepkilerde bulunmak durumundadır. Kişiliğinin bir anlamda en orijinal kısmını oluşturan bu yaşantılar hem yeni yaşantıların eklenmesiyle hem de çocukluğundakilerin aynısının tekrarlanmasıyla yaşam boyu sürer gider. Bir kimse başkalarına ve çevresine tepkide bulunurken veya uyarıcı gönderirken, eğer bu kayıtlarını harekete geçirecek şekilde enerjisini yönlendiriyorsa veya bu kayıtlardakine benzer yeni yaşantılar içindeyse Çocuk ego durumundadır (Özerk; 2008, s.15)

Yetişkin ego durumu (Y): Kişinin, "Şimdi ve Burada" tepkilerini verirken ortaya çıkan duygu, düşünce ve davranışları içermektedir. Şu andaki gerçeğe uygun olan ve diğer iki kategoriden uzak duygu, düşünce ve davra- 
nış örüntüleri takımıdır. Yetişkin ego durumu, geçmişe değil şu ana yönelik olduğundan, Ebeveyn Ego durumundan farklıdır. Bir kimse başkalarına ve çevresine tepkide bulunurken ve uyarıcı gönderirken, eğer bu kayıtlarını harekete geçirecek şekilde enerjisini yönlendiriyorsa veya bu kayıtlardakine benzer yeni yaşantılar içindeyse Yetişkin Ego durumundadır (Özerk, 2008, s.15-16).

\subsubsection{Fonksiyonel analiz}

Fonksiyonel analiz, bireylerin ego durumları malzemelerini hem içsel olarak hem de başkalarıyla ilişkilerinde harekete geçirmeleri ile ilgilidir. Bu nedenle günlük yaşamda dışarıdan görülebilenlere ilişkindir. İkinci düzey fonksiyonel analizde Ebeveyn ve Çocuk ego durumları ikiye ayrılmaktadır. Yetişkin ego durumu ise sınıflandırılmamaktadır.

Íkinci düzey fonksiyonel (standart) analiz: Ebeveynlerin çocukları için yaptıkları en temel şey, onların dünyayı nasıl algılayacaklarını ve dünyayla nasıl baş edeceklerini belirlemektir. Ebeveyn Ego durumu yarg1, değer, görüş ve tutumlarla belirginleşmektedir bunlar;

Koruyucuebeveyn (KE): Koruyucu Ebeveyn; ilgili, özen gösterici, bağışlayıc1, destekleyici, izin verici, şefkatli, koruyucu ve endişelidir.

Eleştirel ebeveyn (EE): Eleştirel Ebeveyn ise inatçı, güçlü, ilkeli, cezaland1rıcı ve görev yükleyicidir. Ebeveyn Ego durumu kişinin kendisinin diğer ego durumlarına veya başkalarının ego durumlarına karşı işlev görür (Edwards, 1966; Akt: Akkoyun; 2011, s.22; Özerk, 2008, s.16).

Yetişkin ego durumu (Y): Yetişkin Ego durumu olasılıkları hesaplayan bir bilgisayar gibi işlev görmekle beraber, bilgisayardan farklı olarak her zaman çalışmaya hazır haldedir. Daha çok nörofizyolojik yapıdan kaynaklandığından, dünyadaki bilgileri toplamak ve verileri işlemek üzere bağımsız olarak çalışır (Akkoyun, 2011, s.23).

Doğal çocuk (DÇ) : Doğal çocuk dünyadaki ebeveyn figürlerine tepkide bulunmaktan uzak durarak, kendini spontan olarak ifade eder (Özerk, 2008, s.28).

Uygulu çocuk (UÇ): Uygulu çocuk ise doğal çocuktan farklı olarak, sanki ebeveynleri onu dinliyormuş ya da gözlüyormuş gibi tepkide bulunur. 
Ancak aralarındaki önemli farklılık, davranışın başka bir kimseye uymaya yönelik olup olmamasındadır (Özerk, 2008, s.28).

\section{Sabitlik hipotezi ve egogram}

TA kuramına göre bireyler hangi ego durumu daha çok gelişmiş ise o ego durumuna özgü davranışları iletişim sürecine yansıtma eğilimindedirler (Akbağ ve Deniz 2003, s.268). Akbağ ve Deniz, Dusay ve Dusay'nin bu durumu egogram ve sabitlik hipotezi ile açıklamaya çalıştığını söylemiştir. Bar grafiği ile gösterilen egogram fonksiyonel analizde beş ego durumunda bireyin hangi Ego Durumu ile iletişim kurduğunu gösterir. Egogramda alçak kolonlar iletişim sürecinde düşük enerji ve az zaman harcandığını, yüksek kolonlar ise fazla zaman ve fazla enerji harcandığını gösterir. Bu durum ise enerjisi fazla olan ego durumunun daha sık kullanıldığını gösterir. Aşağıdaki şekil 1'de psişik enerjinin iyi dengelenmiş ve düzenli bir sisteme sahip bir kişilik yapısı işaret edilmektedir (Akbağ ve Deniz, 2003, s.268-269).

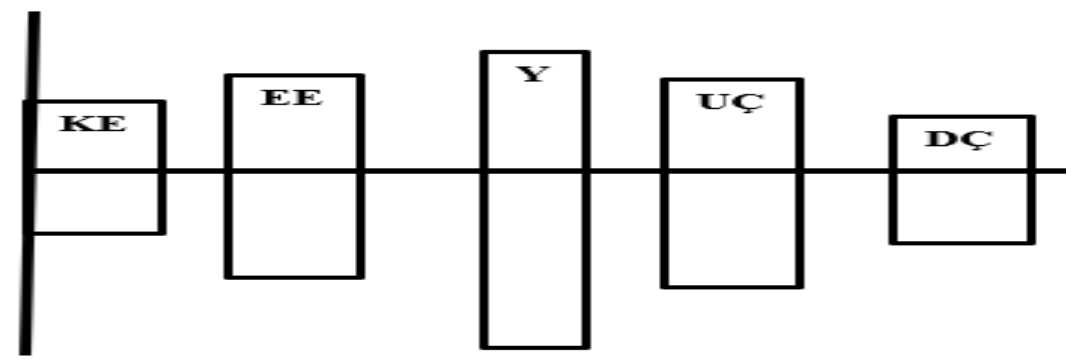

Şekil 1. Çan eğrisi biçimindeki egogram (Dusay ve Dusay' den aktaran Akbă̆ ve Deniz, 2003, s.263-293).

\section{Araştırmanın Amacı ve Yöntemi}

\subsection{Araştırmanın Amacı}

Araştırmanın genel amacl; üniversite sınavlarına (YGS ve LYS) hazırlanan lise son sınıf öğrencilerinin kendilerinde algıladıkları ego durumları ile sı- 
nav kaygısı düzeyleri arasında anlamlı bir ilişki olup olmadığını incelemektir. Yapılan literatür taramalarına bakıldığı kadarıyla araştırma konusunun ülkemizde çalışılmadığ1 görülmüştür.

Araştırmada genel amaç doğrultusunda şu sorulara da yanıt aranmıştir:

- Sınav Kaygı Ölçeğinin alınan puanlar cinsiyete göre farklılık göstermekte midir?

- Öğrencilerin ego durumları cinsiyete göre farklılık göstermekte midir?

- Öğrencilerin ego durumlarının genel sınav kaygısı düzeyleri arasında anlamlı bir ilişki var mıdır?

- Transaksiyonel Analiz kuramı çerçevesinde enerjinin yoğunluğu (kullanımı), ego durumlarına göre öğrencilerde farklılık göstermekte midir?

\subsection{Evren ve örneklem}

$\mathrm{Bu}$ çalışma ilişkisel tarama modelindedir. Çalışma grubunu (örneklemi) 2014-2015 eğitim öğretim yılında Ankara ili Çankaya merkez ilçesinde bulunan ve Anadolu Lisesi'nde okuyan, aynı zamanda da özel dershanelere devam eden lise son sınıf öğrencileri oluşturmaktadır. Araştırmanın örneklemini altı okuldan küme örnekleme yoluyla seçilen 307'si kız, 228'i de erkek olmak üzere toplam 535 liseli öğrenci oluşturmaktadır.

\subsection{Yöntem}

Araştırmada, öncelikle İstanbul Arel Üniversitesi Etik Kurulu' ndan onay alınmıştır. Sonrasında araştırma yapılması planlanan okullarla ilgili olarak İl ve İlçe Milli Eğitim Müdürlükleri ve Okul yöneticilerinden izin alınmıştır. Örneklem grubu öğrencilerine araştırmanın amacı açılanmış, onam formları alınanlara okul rehberlik saatlerinde araştırmacının gözetimi altında (yüz yüze) uygulama yapılmış ve araştırmacı tarafından formlar toplanmıştır. 


\subsection{Araştırmanın Sayıltıları}

1. Katılımcıların (YGS ve LYS sınavına hazırlanan ve özel dershanelere devam eden lise son sınıf öğrencileri) Ego Durumu Ölçeğine, Sınav Kayg1sı Ölçeğine ve demografik değişkenleri belirleyen sorulara verdikleri yanıtların onların gerçek düşüncelerini yansıttığı varsayılmaktadır.

2. Araştırmada kullanılan ölçme araçları ülkemize uyarlanmış geçerliliği ve güvenilirliği yapılmıştır.

3. Araştırmanın çalışma grubu, ego durumları ile sınav kaygısı arasındaki ilişkiyi araştırma evreni bağlamında temsil edebilecek nitelik ve niceliktedir.

\subsection{Araştırmanın Sınırlılıkları}

1. Araştırma, evren bakımından 2014-2015 eğitim öğretim yılında Ankara ili Çankaya ilçesinde bulunan resmi Anadolu liselerinde okuyan ve aynı zamanda özel dershanelere devam eden lise son sınıf öğrenciler ile sinırlıdır.

2. Katılımcıların kendilerini algıladıkları ego durumunun belirlenmesi, "Ego Durumları Ölçeği” verileri ile sinırlıdır.

3. Katılımcıların kendilerinde algıladıkları sınav kaygı düzeyleri "Sınav Kaygısı Ölçeği" verileri ile sınırlıdır.

4. Araştırma, amaçlar bölümündeki sorularla sınırlıdır.

5. Araştırma, kullanılan istatistiksel analizlerle sınırlıdır.

\subsection{Veri toplama araçları}

Araştırmada veri toplamak amacı ile katılımcılara geçerlilik ve güvenilirlik çalışmaları yapılmış toplam 20 ifadeden oluşan ve iki alt ölçekten (Kuruntu, duyuşsal) oluşan Sınav Kaygısı Ölçeği yine geçerlilik güvenilirlik ve uyarlama çalışması yapılmış 95 ifadeden oluşan Ego Durumları Ölçeği ve araştırmacı tarafından geliştirilmiş olan Kişisel Bilgi Formu uygulanmiştır. 


\subsubsection{Sınav kaygısı ölçeği (SKÖ)}

Orijinalini Spielberger ve arkadaşlarının geliştirdiği daha sonra Öner tarafından Türkçeye uyarlan Sınav Kaygısı Ölçeği öğrencilerin kendi kendilerini değerlendirmesi esasına dayanır. Sınav Kaygı Ölçeği toplam 20 sorudan oluşmaktadır. Sınav kaygı ölçeğinden üç ayrı puan elde edilmektedir. Bunlar; a) sınav Kaygı Ölçeği Tümtest (SKÖ-T) puanı, b) Sekiz maddeden oluşan Sınav Kaygı Ölçeği Kuruntu (SKÖ-K) puanı ve c) Oniki maddeden oluşan Sınav Kaygısı Ölçeği Duyuşsal (SKÖ-D) puanıdır .

Her madde için "hemen hiçbir zaman", "bazen", "sık sık" ve "hemen her zaman" olmak üzere dört seçenekli bir likert tipi ölçeği vardır. Üç türlü puan çıarılır: Kuruntu, duyuşsallık ve tüm test puanı. Envanterden alınabilecek en yüksek tüm test puanı 80 'dir. Kuruntu alt test puanları 832; Duyuşsallık alt test puanları 12-48 arasında değişebilir. Envanterden elde edilen puanların yüksekliği; kuruntunun, duyuşsallığın ve sınav kaygısının yüksekliğini gösterir. Test-tekrar test güvenirliği, Pearson Momentler Çarpımı korelasyon katsayıları 0.70 ile 0.90 arasında, Kuder-Richardson güvenirliği, KR-20 değeri, 0.70 ile 0.90 arasında, madde-toplam test puanı korelasyonları ile hesaplanan içtutarlılık katsayıları tüm test için 0.46 , alt testler için 0.43 ve ölçmenin standart hatası, örneklemin eğitim düzeyine göre 3.49 ile 4.63 puan arasında değiştiği bulunmuştur. Ölçüt-bağımlı geçerliği, Sürekli Kaygı Ölçeği ve sınav koşulunda Durumluluk Kaygı Ölçeği puanları ile korelasyonları .39 ile 0.70 arasında değişmiştir. Yapı geçerliği, Öz Kavram Ölçeği ile orta düzeyde ve olumsuz (- 0.31 ile - 0.56); uyum güçlüklerinin yansıtıldığı Minesota Danışma Envanteri alttest puanları ile sınav kaygısı puanları arasında orta düzeyde ve olumlu (0.60 ile 0.22) ilişki saptanmıştır (Öner,1990, s.2,12; Gençdoğan, 2006, s.155).

\subsubsection{Ego durumları ölçeği}

Ölçeğin orijinali Williams tarafından 1978' de geliştirilmiş ve Arı (1989) tarafından Türk kültürü için yeniden geliştirme çalışmaları yürütülmüştür. Ölçek, insanı tanımlayan 95 sıfattan oluşan bir listeden oluşmaktadır. Ölçeğin geçerlik çalışmalarında, mantıksal ve istatistiksel yaklaşımdan ya- 
rarlanılmıştır. Mantıksal geçerlik ile ilgili olarak uzman kanısına başvurulmuştur. Ölçeği oluşturan sıfatların puanlanmasında yararlanılan altı hakemin değerlendirmeleri arasındaki yüksek tutarlılık, ölçeğin mantıksal geçerliği için önemli bir kanıt sayılmıştır.

Ölçeğin benzer ölçekler geçerliği, Akkoyun ve Bacanlı (1988) tarafından Türkçe' ye uyarlanan "Gough ve Heilbrun Sifat Tarama Listesi" kullanılarak gerçekleştirilmiştir. Her iki ölçeğin benzer alt ölçekleri arasında Eleştirel Ebeveyn için $r=0.87$, Koruyucu Ebeveyn için $r=0.91$, Yetişkin için $r=0.93$, Doğal Çocuk için $r=0.76$ ve Uygulu Çocuk için $r=0.70^{\prime}$ lik korelasyon katsayıları bulunmuştur. Güvenirlik ile ilgili çalışmalarda ise, testin aralıklı tekrarı yönteminden yararlanılmıştır. İki uygulamadan elde edilen ego durumu puanları arasında Eleştirel Ebeveyn için $r=0.73$, Koruyucu Ebeveyn için $r=0.83$, Yetişkin için $r=0.81$, Doğal Çocuk için $r=$ 0.77 ve Uygulu Çocuk için $r=0.74$ 'lük tutarlılık katsayıları elde edilmiştir.

\subsubsection{Kişisel bilgi formu}

Araştırıcı tarafından oluşturulan bu formda, öğrenciler ve ailelerinin sosyo-demografik özellikleriyle ilgili sorular (okul, sınıf, yaş, cinsiyet vb.) yer almaktadır.

\subsection{Verilerin analizi}

Araştırmada, üniversite sınavına hazırlanan ve özel dershanelere devam eden lise son sınıf öğrencilerinin kendilerinde algıladıkları ego durumları ile sınav kaygı düzeyleri arasındaki ilişki incelenmiştir. Veriler araştırmanın amacı doğrultusunda betimsel ve ilişkisel istatistiki işlemlere göre çözümlenmiştir. Öncelikle öğrencilerin cevapladığı Sınav Kaygı Ölçeği ve Kişisel Bilgi Formun'da yer alan veriler SPSS for Windows 20.0 ortaminda kodlanmıştır. Ego Durumları Ölçeğinden alınan puanlar Microsoft Excel 2013 ortamında hesaplanmış ve elde edilen veriler SPSS for Windows 20.0 paket programına girilmiş ve analiz edilmiştir. Araştırmada öncelikle Lise 12. sınıfa devam eden öğrencilerin Kişisel Bilgi Formuna verdikleri cevaplara göre demografik özellikler ve diğer bilgiler için betimsel istatistiki frekans ve yüzde hesapları yapılmış yine demografik değişkenler için de Bağımsız Örneklem İki Yönlü Varyans Analizi yapılmıştır. Cinsiyet ve sınav 
kaygısı tümtest ve alt ölçekleri arasındaki ilişki için Bağımsız Örneklem ttesti yine öğrencilerin ego durumlarının cinsiyete göre farklılık gösterip göstermediği ile ilgili de veriler normal dağılım göstermediği için de KiKare ilişki testi uygulanmıştır. Daha sonra ego durumlarından her birinin sınav kaygısı tümtest ve alt ölçekleri ile arasında anlamlı bir ilişkinin olup olmadığını belirlemek için bu ego durumlarına sahip olan ve olmayan öğrencilerin sınav kaygısı puan ortalamaları hem tüm test hem de alt testler boyutlarında t testi ile karşılaştırılmıştır. Böylece bu ego durumlarında olan ve olmayan katılımcıların sınav kaygıları arasında anlamlı bir farklılık olup olmadı̆̆ına bakılmıştır. Ego durumu ve cinsiyet değişkenlerinin sınav kaygısı ve alt ölçeklerini birlikte oluşturdukları değişimlerin incelenebilmesi için Bağımsız Örneklem İki Yönlü Varyans Analizi uygulanmıştır. Araştırmada İstatistiksel olarak p değeri .05 olarak kabul edilmiş ve değerlerin bunlardan küçük olması anlamlılık olarak değerlendirilmiştir.

\section{Bulgular}

Çalışma grubumuzdaki öğrencilerin cinsiyete bağlı olarak sınav kaygısı tüm test (SKÖ-T) ve alt ölçekleri (SKÖ-D ve SKÖ-K) ortalamaları arasında anlamlı bir farklılık olup olmadığını belirlemek amacıyla kız ve erkek katılımcıların sınav kaygısı puan ortalamaları hem tüm test hem de alt testler boyutlarında t testi ile karşılaştırılmıştır.

Tablo 1. Kız ve erkek öğrencilerin sınav kaygısı tüm testinden aldıkları puanların ortalamaları (M), standart sapmaları (ss), sd, t ve p Değerleri

\begin{tabular}{llllllll}
\hline & Cinsiyet & $\mathbf{N}$ & $\mathbf{M}$ & $\mathbf{s s}$ & $\mathbf{t}$ & $\mathbf{s d}$ & $\mathbf{p}$ \\
\hline \multirow{2}{*}{ SKÖ-T } & K1z & 307 & 44.08 & 11.679 & 3.347 & 533 & $\mathbf{. 0 0 1}$ \\
& Erkek & 228 & 40.70 & 11.377 & & & \\
\hline \multirow{2}{*}{ SKÖ-D } & K1z & 307 & 27.28 & 7.320 & 3.602 & 533 & $\mathbf{. 0 0 0}$ \\
& Erkek & 228 & 25.03 & 6.923 & & & \\
\hline \multirow{2}{*}{ SKÖ-K } & K1z & 307 & 16.80 & 5.136 & 2.538 & 533 & $\mathbf{. 0 1 1}$ \\
& Erkek & 228 & 15.67 & 5.001 & & & \\
\hline
\end{tabular}

Tablo 1.'de görüldüğü gibi kız ve erkek öğrencilerin sınav kaygısı ortalamalarının gerek tümtest gerekse duyuşsal ve kuruntu alt test boyutlarında anlamlı derecede farklılaştığı görülmüştür $(\mathrm{p}<0,05)$. 
Kız öğrencilerin puan ortalamaları tüm alt boyutlarda ve tüm test boyutunda anlamlı derecede yüksektir. Buna göre kız öğrenciler tüm test, duyuşsal ve kuruntu alt boyutlarında daha yüksek sınav kaygısı düzeyine sahiptir. Kız öğrencilerin Tümtest Sınav Kaygısı ölçeğinden aldıkları puanların ortalaması $(\mathrm{M}=44,08$; ss=11,679) erkeklerin puanlarının ortalaması $(\mathrm{M}=40,70$; ss=11,377)'dir. Bu iki ortalama arasındaki farka ilişkin $\mathrm{t}=3,347$, değeri $\mathrm{p}<.05$ düzeyinde anlamlı bulunmuştur.

Yine Kız öğrencilerin Sınav Kaygısı ölçeği alt ölçeği olan Duyuşsal Kayg1 puanların ortalaması ( $\mathrm{M}=27,28$; ss=7,320) erkeklerin puanlarının ortalaması $(\mathrm{M}=25,3 \text {; } \mathrm{ss}=6,923)^{\prime}$ tür. Bu iki ortalama arasındaki farka ilişkin $\mathrm{t}=3,602$, değeri $\mathrm{p}<.01$ düzeyinde anlamlı bulunmuştur.

Ayrıca Kız öğrencilerin Sınav Kaygısı ölçeği alt ölçeği olan Kuruntu puanların ortalaması $(\mathrm{M}=16,80=$; $\mathrm{ss}=5,136)$ erkek öğrencilerin puanlarının ortalamasından $(\mathrm{M}=15,67 ; \mathrm{ss}=5.001)$ yüksektir. Bu iki ortalama arasındaki farka ilişkin $\mathrm{t}=2,538$, değeri $\mathrm{p}<.05$ düzeyinde anlamlı bulunmuştur.

Tablo. 2. Örneklemimizi oluşturan kız ve erkek öğrencilerin ego durumlarına göre da乌̆ılımı

\begin{tabular}{llllllll}
\hline \multicolumn{7}{c}{ Ego Durumları } & Toplam \\
\hline Cinsiyet & KE & KE & Y & UÇ & DÇ & \\
& Erkek & 13 & 156 & 26 & 18 & 93 & 306 \\
& 12 & 101 & 26 & 18 & 70 & 227 \\
\hline Toplam & & $\mathbf{2 5}$ & $\mathbf{2 5 7}$ & $\mathbf{5 2}$ & $\mathbf{3 6}$ & $\mathbf{1 6 3}$ & $\mathbf{5 3 3}$ \\
\hline
\end{tabular}

Yukarıda Tablo 2.'de de görüldüğü öğrencilerin kendilerini en fazla KE ego durumunda (\%48, ikinci olarak da DÇ ego durumunda (\%30) en az olarak da EE ego durumunda (\%4) ve UÇ ego durumunda (\%6) algıladıkları görülmektedir. Kız öğrenciler kendilerini \%50,9 düzeyinde KE, \%30,3 düzeyinde DÇ, \%8,4 Yetişkin, \%5,8 UÇ ve \%4,2 EE ego durumunda alg1lamakta iken, erkek öğrenciler kendilerini \%44,4 KE, \%30,8 DÇ, \%11,4 Y, $\% 7,9$ UÇ ve \%5,2 düzeyinde EE düzeyinde algılamaktadır.

Bununla ilintili olarak öğrencilerin kendilerinde algıladıkları her bir ego durumunun sınav kaygısı ile ilişkisine bakılmış ve anlamlı ilişkinin bulunduğu ego durumu aşağıda verilmiştir.

Çalışmaya katılan öğrencilerin Yetişkin ego durumu ile sınav kaygısı tüm test (SKÖ-T) ve alt ölçekleri (SKÖ-D ve SKÖ-K) arasında anlamlı bir 
ilişki olup olmadığını belirlemek amacıyla $t$ testi ile karşılaştırılmıştır. Daha sonra t değerleri korelasyon değerlerine çevrilerek eğer anlamlı bir farklılık varsa bu farkın "ilişki" olarak yorumlanabileceği korelasyon değerleri elde edilmiştir.

Tablo 5. Yetişkin ego durumu ile sınav kaygısı tüm test ve alt ölçekleri arasında anlamlı bir ilişki olup olmadığınının t testi ile karşılaştırılması

\begin{tabular}{llllllll}
\hline & Ego durumu & $\mathbf{N}$ & Ortalama & ss & $\mathbf{t}$ & df & $\mathbf{p}$ \\
\hline Sinav Kaygisı & Yetişkin & 52 & 40,71 & 12,246 & $-1,256$ & 533,209 \\
Tümtest & Yetişkin değil & 483 & 42,85 & 11,591 & & & \\
\hline Sinav Kaygisı & Yetişkin & 52 & 25,85 & 7,805 &,- 500 & 533,617 \\
Duyuşsal & Yetişkin değil & 483 & 26,37 & 7,176 & & & \\
\hline Sinav Kaygisı & Yetişkin & 52 & 14,87 & 5,080 & $-2,167$ & 533 & $0,031^{*}$ \\
Kuruntu & Yetişkin değil & 483 & 16,47 & 5,088 & & & \\
\hline
\end{tabular}

Tablo 5.'te de görüldüğü gibi yapılan analiz sonucunda Yetişkin ego durumunda olan ve olmayan öğrencilerin sınav kaygısı ortalamalarının tüm test ve duyuşsal alt test boyutlarında anlamlı derecede farklılaşmadığı görülmüştür. Fakat kuruntu alt boyutunda Yetişkin ve Yetişkin olmayan ego durumuna sahip öğrencilerin kuruntu alt boyutundaki puanlar1nın ortalamaları arasında düşük de olsa anlamlı bir farklılık olduğu gözlenmiştir $(\mathrm{p}<0,05)$.

Bu durumun ilişki olarak değerlendirilip değerlendirilmeyeceğini gösterebilmek için $t$ değerleri korelasyon değerlerine çevrilmiş ve aşağıda gösterilmiştir.

Tablo 6. Yetişkin ego durumuna sahip olan ya da olmayan öğrencilerin sınav kaygısı düzeylerine ilişkin t değerlerinin korelasyon değerlerine çevrilmesi

\begin{tabular}{ll}
\hline $\mathrm{r}$ & Yetişkin ego durumu \\
\hline Sinav Kaygısı Tümtest & 0,05 \\
\hline Sinav Kaygısı Duyuşsal & 0,02 \\
\hline Sinav Kaygısı Kuruntu & $0,09^{*}$ \\
\hline${ }^{*} \mathbf{p}<\mathbf{0 , 0 5}$ &
\end{tabular}

Yukarıdaki Tablo 6.'da da görüleceği gibi Yetişkin ego durumu ile sınav kaygısı tüm test ve duyuşsal alt boyutu arasında anlamlı bir ilişki olmadığı görülmüştür. Ancak sınav kaygısı ölçeğinin kuruntu alt boyutu ile 
öğrencilerin kendilerinde algıladıkları Yetişkin ego durumu arasında düşük de olsa anlamlı bir ilişki olduğu bulunmuştur.

Ayrıca aynı analizler ve testler Koruyucu Ebeveyn (KE), Doğal Çocuk (DÇ) ve Uygulu Çocuk (UÇ) ego durumun için de yapılmıştır. Yapılan analizler sonucunda Koruyucu Ebeveyn (KE), Doğal Çocuk (DÇ) ve Uygulu Çocuk (UÇ) ile genel sınav kaygısı düzeyleri ve sınav kaygısı sınav kaygısı tümtest (SKÖ-T) ve alt ölçekleri (SKÖ-D ve SKÖ-K) boyutları arasında anlamlı bir ilişki olmadığı bulunmuştur.

\section{Tartışma ve Yorum}

Bu bölümde var olan kuramsal literatür ve deneysel çalışmaların desteği ile araştırmada ele alınan amaçların sırası göz önünde tutularak elde edilen bulguların, tartışılması ve mantıksal yorumuna yer verilmiştir. Ülkemizde üniversiteye giriş sınav sistemi ilk olarak Öğrenci Seçme ve Yerleştirme Sınavı (ÖSYS) adıyla 1974 yılında başlamış olup 2019 yılına kadarki süreçte 8 kez değişikliğe gidilmiştir. 1974 ve 1975 yıllarında aynı gün sabah ve öğleden sonra olmak üzere iki oturumda gerçekleşen sinav, 19761980 yılları arasında aynı günde ve tek bir oturumda uygulanmış 1981 yılında ise Öğrenci Seçme Sınavı (ÖSS) ve Öğrenci Yerleştirme Sınavı (ÖYS) olmak üzere iki basamaklı hale getirilmiştir. Bir yıl sonra (1982' de) sistemde yine bir değişikliğe gidilmiş ve ortaöğretim kurumlarından alınan diploma notları yani ortaöğretim başarı puanı (OBP) belli ağırlıkta sınav puanlarına eklenmiştir. Bu sistem 1987 yılına kadar sürmüş, 1987-1999 yılları arasında ise sınav, alanlara (Matematik+Fen, Türkçe+Matematik, Türkçe+Sosyal gibi) ayrılmış ve öğrencilere hangi alanlardan sınava gireceklerse o alandaki soruları cevaplama olanağı tanınmıştır. Sistem 1999 yılında tekrar ÖSS adıyla tek basamaklı hale gitirilmiş, 2006 yılında ise soruların lise müfredatına ve sınıflara göre ağırlıklarında değişikliğe gidilmiştir. Sınav sisteminde 2010 yılında tekrar değişikliğe gidilmiş ve sınav, Yükseköğretime Geçiş Sınavı (YGS) ve Lisans Yerleştirme Sınavı (LYS) adıyla iki aşamalı hale dönüştürülmüştür. Son olarak da 2018 yılında değişikliğe gidilerek sınavın adı Yükseköğretim Kurumları Sınavı (YKS) olarak değiştirilmiş sınavda akıl yürütme, mantıklı düşünme odaklı sözel ve sayısal becerileri ölçme, Türkçe' yi doğru kullanma, okuma, yazma, kavrama ve dil hakimiyeti becerisinin ölçüleceğinin ifade edildiği bir sisteme 
geçilmiş, sınavın aynı gün öğleden önce ve öğleden sonra olmak üzere iki aşamada gerçekleştirilmesine karar verilmiştir (http://www.yeniakit.com.tr). Sınav sistemindeki bu değişikliklerin bile tek başına öğrencilerin sınav kaygılarının nedenlerinden biri olacağı eğitim, psikoloji ve psikiyatri alanındaki hemen herkes tarafından tartışma götürmez bir gerçekliktir. Zaten bu sürecin öğrenciler bakımından kaygı oluşturucu ve yıpratıcı olduğu belirtilmektedir (Yıldırım, 2008; Çiçek, 2018).

Çapulcuoğlu ve Gündüz' ün (2013), lise öğrencilerinde tükenmişliği yordayan değişkenleri inceledikleri çalışmada, sınav kaygısının lise öğrencilerinin tükenmişlik düzeylerini yordayan değişkenlerden önemli değişkenlerden biri olduğu görülmüştür. Yıldırım ve Ergene (2003), lise son sınıf öğrencilerinin akademik başarılarının yordayıcısı olarak sınav kaygısı, boyun eğici davranışlar ve sosyal destek başlıklı çalışmalarında, s1nav kaygısının akademik başarıyı anlamlı düzeyde yordadığını bulgulamışlardır. Bozanoğlu (2005), lise öğrencileri ile yaptığı deneysel çalışmada, grup rehberliği çalışmalarının güdülenme, benlik saygısı ve sınav kaygısı üzerinde olumlu etkilerinin olduğunu göstermiştir. Benzer bir çalışma Koruklu, Öner ve Oktaylar (2006) tarafından gerçekleştirilmiştir. S1nav kaygısı ile başaçıkma programının sınav kaygısına etkisine yönelik gerçekleştirilen deneysel çalışmada, gerçekleştirilen çalışmanın anlamlı düzeyde sınav kaygısını azalttığını bulgulamışlardır.

Ergene (2011) de yaptığı çalışmada lise öğrencilerinin sınav kaygısı ile akademik performans düzeyleri arasında negatif yönde anlamlı düzeyde ilişki olduğunu bulgulamıştır. Araştırmalarda elde edilen bu bulgular üniversite sınavına hazırlanan lise öğrencilerinin sınav kaygılarını azaltmaya yönelik çalışmaların ne denli önemli olduğunu göstermektedir.

Araştırmanın amaçlarından biri lise 12. Sınıf öğrencilerinin sınav kaygı düzeylerinin cinsiyete göre farklılaşıp farklılaşmadığının test edilmesidir. Araştırmaya katılan lise 12. Sınıf öğrencilerinin Sınav Kaygı Ölçeği; sınav kaygısı tümtest, sınav kaygısı duyuşsal ve sınav kaygısı kuruntu puanları cinsiyet değişkenine göre karşılaştırıldığında kız öğrencilerin sınav kaygisı tümtest, sınav kaygısı duyuşsal ve sınav kaygısı kuruntu puanları düzeyleri erkek öğrencilerin sinav kaygı düzeylerinden istatistiksel olarak anlamlı düzeyde yüksek bulunmuştur. Bu bulgu, Güler ve Çakır' in (2013, s.89) lise son sınıf öğrencilerinin sınav kaygısını yordayan değişkenleri inceledikleri ve aynı ölçeği kullandıkları çalışma bulgusuyla örtüşmektedir. 
Araştırmanın bu sonucu, başka benzer araştırmaların sonuçları ile de tutarlılık göstermektedir (Zeidner, 1990; Ök, 1990; Erkan, 1991; Köklü,1994; Berengi,1996; Çankaya, 1997; Ekşi, 1998; Ünal, 2006, Alyaprak, 2006; Başoğlu, 2007, Akt. Hanımoğlu 2010, s.72). Yapılan araştırmalarda, bu araştırmada bulgulandığı gibi, kız öğrencilerin SKÖ'nin tümtest, duyuşsallık ve kuruntu alt ölçeğine ilişkin sınav kaygısı düzeylerinin erkeklerinkinden anlamlı olarak daha yüksek olduğu bulunmuştur.

Araştırmanın amaçlarından bir diğeri ise 12. Sınıf öğrencilerinin ego durumları dağılımlarının cinsiyete göre farklılaşıp farklılaşmadığının test edilmesidir. Araştırmaya katılan lise 12. sınıf öğrencilerinin Eleştirel Ebeveyn, Koruyucu Ebeveyn, Yetişkin, Uygulu Çocuk ve Doğal Çocuk ego durumları cinsiyet değişkenine göre karşılaştırıldığında kız ve erkek öğrencilerin ego durumları arasında istatistiksel olarak $(p<0,05)$ anlamlı düzeyde farklılık bulunmamıştır. Yalnız istatistiksel olarak anlamlı olmasa da kızların ( $\mathrm{N}=156)$ erkeklere ( $\mathrm{N}=101)$ göre Koruyucu Ebeveyn ego durumuna yığılması manidardır. Elde edilen bulgular Eleştirel Ebeveyn, Koruyucu Ebeveyn ve Doğal Çocuk ego durumu puan ortalamalarının cinsiyete göre farklılık göstermemesi daha önce yapılmış araştırmalarla tutarlılık göstermekte ve bu araştırmaları desteklemektedir (Williams ve Best, 1982; Arı, 1989; Alisinanoğlu, 1995; Akt. Kekler, 2008). Ancak araştırmada Yetişkin ve Uygulu Çocuk ego durumunun cinsiyete göre farklılık göstermemesi bulgusu yukarıda sözü edilen araştırmaların sonuçlarıyla uyuşmamaktadır. Bununla birlikte araştırmada elde edilen bulgular Akbağ'ın (2000, s.91) yaptığı araştırmanın bulgularıyla (Yetişkin ego durumu hariç diğer ego durumlarıyla) uygunluk göstermektedir.

Araştırmanın amaçlarından bir diğeri ise lise 12. sınıf ğrencilerinin Transaksiyonel Analiz kuramı çerçevesinde enerji yoğunluğunun (kullanımının) ego durumlarına göre birbirinden farklılık gösterip göstermediğinin bulgulanması idi. Çalışma grubu öğrencilerinin enerji yoğunlukları Egogram Bar Grafiği yardımı ile yapılmış ve öğrencilerin enerji yoğunluğunun en fazla Koruyucu Ebeveyn Ego (KE) durumunda olduğu görülmüş̧ür. Bu bulgu Akbă̆'1n (2000, s.92) üniversite öğrencileri üzerinde yaptığı çalışma bulgularıyla ve Kekler' in (2008, s.43) liseli ergenlerle yaptığı çalışma bulgularıyla paralellik göstermektedir.

Koruyucu Ebeveyn ego durumu; ilgili, özen gösterici, koruyucu, sempatik bağışlayıcı, destekleyici, şefkatli davranışlarla birlikte kaygılı 
davranışlarla da kendini göstermektedir. Çalışma grubu öğrencilerinin enerjilerini daha çok Koruyucu Ebeveyn ego durumunda kullanmalarının sınav kaygısı ile ilişkili olması TA kuramına göre açıklanabilir bir durumdur. Çünkü TA'ya göre sağlıklı bir kişilik için her bir ego durumunun kullanılması gerekmektedir ve içinde bulunulan duruma göre de enerji ilgili ego durumunda yoğunlaşmalıdır. Bunun da Yetişkin ego durumu denetiminde gerçekleşmesi gerekir (Akbağ ve Deniz, 2003, s.268). KE ego durumu davranışları göz önüne getirildiğinde kaygıyı azaltıcı bir fonksiyonda bulunacağı aşikardır. Dolayısıyla enerjinin KE ego durumunda daha yoğun olarak kullanılmasının, öğrencilerin sınav kaygılarına yönelik bir tepkileri olduğu düşünülebilir.

\section{Sonuç ve Öneriler}

$\mathrm{Bu}$ araştırmanın sonuçları ve amaçları doğrultusunda aşağıdaki öneriler sunulmuştur. Araştırma bulguları doğrultusunda, üniversite giriş sınavına hazırlanan öğrencilerın sınav kaygısını azaltmaya yönelik olarak enerjilerini yoğunlaştırdıkları ego durumunun KE ego durumu olduğu, TA kuramına göre de enerjinin KE ego durumunda yoğunlaşmasının fonksiyonel olduğu gözönünde bulundurulduğunda, liselerdeki PDR birimi çalışanlarınca öğrencilerin ebeveynlerine, çocuklarına karşı KE ego durumundan davranışlar göstermelerinin sağlanmasına yönelik çeşitli seminerler düzenlenebilir.

Çalışma grubu öğrencilerin anne babalarının öğrenim düzeyleri (annelerin $\% 37,7^{\prime}$ sinin lise, $\% 37,7^{\prime}$ sinin üniversite ve $\% 5,1^{\prime}$ inin lisansüstü, babaların ise $\% 30,4^{\prime}$ ünün lise, $\% 46,1^{\prime}$ inin üniversite $\% 8,9$ lisansüstü) dikkate alındığında ebeveynlerin belli bir bilinç düzeyinde olduğu varsayıldığında bile öğrencilerde bulgulanan kaygı düzeylerinin ortalamanın üzerinde olması düşündürücüdür. Dolayısıyla bu tür eğitimlerin gerekli olduğu görülebilmektedir.

TA kuramı çerçevesinde Yetişkin ego denetiminde ego bütünlüğünün ve enerji yoğunluğunun fonksiyonel biçimde kullanılmasının sınav kaygı düzeyini azaltmaya olumlu etkisinin olduğu görülmektedir. Bu bağlamda öğrencilere bu farkındalığı kazandırmak adına PDR birimleri çalışanları tarafından veya alandaki uzmanlar aracılığıyla eğitimler düzenlenebilir. 
Dahası PDR çalışanlarına, öğrencilere yönelik bireysel ya da grup danışmanlığı çalışmaları yapmaları da önerilebilir.

Araştırmada kız öğrencilerin erkek öğrencilere kıyasla sınav kaygı düzeylerinin anlamı düzeyde yüksek olduğu görülmüştür ve bu bulgu başka araştırmalarla da örtüşmektedir. Dolayısıyla okul Psikolojik Danışmanları, bireysel ya da grup danışmanlığı çalışmalarında kız öğrencilere ağırlik verebilirler.

Araştırma farklı kategorilerde yer alan liselerde (Fen Liseleri, Proje Okulları, Anadolu Liseleri, Endüstri Meslek Liseleri, Sosyal Bilimler Liseleri, Spor Bilimleri Liseleri, Güzel Sanatlar Liseleri) gerçekleştirilebilir, karşılaştırmalı çalışmalara da yer verilebilir.

Başka değişkenler eklenerek ego durumları ve sınav kaygısı ilişkisine eklenen değişken bakımından bakılabilir. 


\title{
EXTENDED ABSTRACT
}

\section{Investigating The Relationship Between Exam Anxi- ety Level And Perceived Ego States Of The High School Students That Prepare To Take University Entrance Exams By Going To Private Classroms}

\author{
Sabahattin Şerif Meşe - Halis Özerk \\ İstanbul Arel University
}

It is expressed that exams that are especially for passing to an upper school (from secondary school to Anatolian high school; from high schools to university) are crucial processes for students; related processes increase stress in students; the stress negatively affects academic success of the students (Dündar, Yapıcı and Topçu, 2008, s.173; Cassady, 2004, s.569; Hanımoğlu., 2011, s.359; Erkan, 1991; Culler and Holahan, 1980; Donald and Katz, 1999; Ekşi, 1998; Yıldırım and Ergene, 2003; Bacanlı and Sürücü, 2006).

Since the system of education in our country is exam-centric, with reference to the expressions, students have an anxious and backbreaking period as from the primary school (Yıldırım, 2008; Çiçek, 2018). There also are several studies that scrutinize the relationship between exam anxiety and care for the self, parental attitudes, decision-making styles of students, limitedness perception schemas, motivation, study habits.

Çakmak, Şahin, and Demirbaş (2017) analyzed the relationship between exam anxiety and self-respect of seventh and eighth-graders. For the results, exam anxiety of female students is significantly higher than the exam anxiety of male students. There is a negatively significant relationship between exam anxiety and self-respect. The same finding can also be seen in Ekşi's (1998) study called "Reviewing Exam Anxiety in University Candidate Teenagers". 
Çiçek and Tanhan (2018) found that there is a significant relationship between exam anxiety levels of high school final year students who prepare for the university entrance exam and self-perceived limitedness perception schemas. They revealed in relation to this finding that there is also a significant relationship between classroom continuity and limitedness schema perception.

Koçkar, Günay, and Şahnur (2002) conducted a study on fourth and fifth graders in primary school. They found that total exam anxiety and subscale delusion are associated with academic success.

With reference to many of foreign studies that analyze exam anxiety and academic performance, academic performance of people who have a high exam anxiety is low (Cooley and Spielberger, 1980, Birenbaum and Nasser, 1994; Hong, 1999; Sullivan,2002; Cassady,2004; Benjamir, 1991; Culler and Holand, 1980; Cassady and Johnson,2002; Brown and Mann, 1991; Zeidner, 1991).

We observe that studies that have been conducted in our country obtained almost the same results (Gündoğdu,1994; Koçkar, Kılıç and Şener, 2002; Erkan, 1991).

For Cognitive-Attention theory, perceiving oneself negatively and repeating it cognitively will bring anxiety and failure (Arnkof and Smith, 1988).

There also are studies which show that there is a significant relationship between exam anxiety and self-respect; psychological problems and psychiatric symptoms (Hambree, 1988; Morris et al., 1981; Neuderth et al., 2009; Kessler et al., 2006; Ameringen et al., 2010; Kutlu, 2001; Kavakçı, Güler and Çetinkaya, 2011).

Erdik and Özpınar (2015) conducted a study on high school final year students prepare for the university entrance exam. They analyzed the relationship between parental attitudes and exam anxiety and concluded that there is a linear significant relation between exam anxiety and authoritarian, nurturing, careless attitude.

As is mentioned above, there are several studies about the relationship between exam anxiety of students in various stages of organized education and various variables such as the sense of self, parental attitudes, learning styles, motivation, study habits, limitedness perception schemas. However, there is not a study on the relationship of students with self- 
perceived ego states. The goal of this research was to analyze this relationship. In other words, we endeavored to analyze whether there is a significant relationship between self-perceived ego states of high school final year students who prepare for university entrance exams (YGS (the transition to higher education examination) and LYS (undergraduate placement exam)) and exam anxiety levels.

This study is in relational screening model. The sample consisted of high school final year students who both study in private classrooms and Anatolian High School in Çankaya central district of Ankara province in the 2014-2015 academic year. Sample of the research was composed of entirely 535 (307 female, 228 male) high school students who were selected by cluster sampling method from six schools.

Exam Anxiety Scale with 20 expressions and two subscales (delusion, affective) whose validity and reliability studies were performed was applied in students to collect data. Moreover, Ego States Scale that is composed of 95 expressions and also Personal Information Form whose validity and reliability studies were performed were applied as well.

This study scrutinized the relationship between exam anxiety levels and self-perceived ego states of high school final year students who prepare for the university entrance exam and continue to private classrooms. Data were analyzed based on descriptive and relational statistical processes in line with the research objective. First of all, data that are in Exam Anxiety Scale and Personal Information Form were coded in the environment of SPSS for Windows 20.0. Scores from Ego States Scale were computed by Microsoft Excel 2013; data were recorded and analyzed in SPSS for Windows 20.0 packaged software.

It is seen at the end of the research that exam anxiety averages of female and male students became significantly different in both fulltest and affective-delusion subtest dimensions $(p<0,05)$. Female students have a higher exam anxiety level in fulltest, affective and delusion sub-dimensions.

It is seen when looking at ego states that students perceive themselves in Nurturing Parent Ego State most (48\%); students perceive themselves in Natural Child Ego State in the second place (30\%); students perceive themselves in Criticizing Parent Ego State in the third place (4\%); finally, the same students perceive themselves in Adaptive Child Ego State in the 
fourth place $(6 \%)$ There is found a low but significant relationship between self-perceived adult ego state and delusion subdimension of the exam anxiety scale.

\section{Kaynakça / References}

Akbağ, M. (2000). Stresle basa çıkma tarzlarının üniversite öğrencilerinde olumsuz otomatik düşünceler, transaksiyonel analiz ego durumlar ve bazı değişkenler açısından incelenmesi. Yayınlanmamış Doktora Tezi, Marmara Üniversitesi Eğitim Bilimleri Enstitüsü İstanbul.

Akbağ, M., ve Deniz, L. (2003). Öğretim elemanı ve öğretmen adaylarının birbirlerine yönelik algıları: Transaksiyonel analiz açısından bir değerlendirme. Kuram ve Uygulamada Ĕ̆itim Bilimleri Dergisi , 2(3), 263-293 .

Akkoyun, F. (2011). Psikolojide işlemsel çözümleme yaklaşımı transaksiyonel analiz. Ankara: Nobel Akademik Yayıncllık Eğitim Danışmanlık.

Akkoyun, H. B. (1990). "ACL-Sıfat tarama listesi'nin Türkçe'ye uyarlanması: TA ego durumları ölçekleri ile bir çalışma.". V. Ulusal Psikoloji Kongresi Psikoloji-Seminer Dergisi Özel Sayısı. Sayı:8. (s. 637643). İzmir: Ege Üniversitesi Edebiyat Fakültesi Yayınları.

Arı, R. (1989). Üniversite öğrencilerinin baskm ben durumları ile bazı özlük niteliklerinin, ben durumlarna, atılganlı ve uyum düzeylerine etkisi. Yayımlanmış Doktora tezi, Hacettepe Üniversitesi Sosyal Bilimler Enstitüsü Ankara.

Arnkoff DB ve Smith RJ (1988) Cognitive processes in test anxiety: An analysis of two assesment procedures in an actual test. Cog Ther Res 12, 425-439.

Bacanlı, F. ve Sürücü M. (2006). İlköğretim 8. sınıf öğrencilerinin sınav kaygıları ve karar verme stilleri arasındaki ilişkilerin incelenmesi. Kuram ve Uygulamada Ĕ̆itim Yönetimi Dergisi / Educational Administration, 45, 7-35.

Birenbaum, M., ve Nasser, F. (1994). On the relationship between test anxiety and test performance. Measurement and Evaluation in Counseling E Development, 27, 293-302. 
Bozanoğlu, İ. (2005). The effect of a group guidance program based on cognitive-behavioral approach on mativation, self-esteem, achievement and test anxiety levels. Ankara University, Journal of Faculty of Educational Sciences, 38 (1), 17-42.

Brown, J. E.ve Mann, L. (1991). Decision-making competence and self esteem: a comparison of parents and adolescent. Journal of Adolescence, 14, 363-371.

Carlson, N. R. (2011). Fizyolojik psikoloji (davranışların nörolojik temelleri) foundations of behavioral neuroscience. (Ç. E. Şahin, Çev.) Ankara: Nobel Akademik Yayıncılık Eğitim Danışmanlık.

Cassady, C. J. (2004). The influence of cognitive test anxiety across the learning testing cycle. Learning and Instruction, 14, 569-572.

Cassady, C. J. ve Johnson. E. R. (2002). Cognitive test anxiety and academic performance. Contemporary Educational Psychology, 27, 270-295.

Cooley, J. E. \& Spielberger, C. D. (1980). Cogntive versus emotional coping responses as alternatives to test anxiety. Cognitive Therapy and Research, 4, 459- 466.

Culler, R. E., ve Holahan, C. J. (1980). Test anxiety and academic performance: the affected study of related behaviors, Journal of Educational Psychology, 72, 16-20.

Çakmak, A., Şahin, H. ve Demirbaş (Akıncı), E. (2017). 7. ve 8. sınıf öğrencilerinin sınav kaygısı ve benlik saygısı arasındaki ilişkinin incelenmesi. Kafkas Üniversitesi e-Kafkas Ĕgitim Araştırmaları Dergisi, 4 (2), 1-9.

Çapulcuoğlu, U. ve Gündüz, B. (2013). Öğrenci tükenmişliğini yordamada setresle başacıkma, sınav kaygısı, akademik yetkinlik ve anne baba tutumları. Eğitim Bilimleri Araştırmaları Dergisi, 3(1), 201-218. DOI Number: http://dx.doi.org/10.12973/jesr.2013.3111a

Çiçek, İ. ve Tanhan, F. (2018). Lise son sınıf öğrencilerinin sinırlılık algı şemaları ile sınav kaygı düzeyleri arasındaki ilişkinin incelenmesi. Batman Üniversitesi Yaşam Bilimleri Dergisi, 8, (1/1), 69-85.

Donald W., Katz R. C., (1999). Reducing test anxiety and improving selfesteem in high school and college students with learning disabilities. Journal of Behavior Therapy And Experimental Psychiatry, 30(3), 191-198. 
Dündar, S., Yapıcı, Ş. ve Topçu, B. (2008). Üniversite öğrencilerinin bazı kişilik özelliklerine göre sınav kaygılarının incelenmesi. GÜ, Gazi Ĕ̆itim Fakültesi Dergisi, 28 (1), 171-186.

Ekşi, P. (1998). Sınav kaygısının üniversite adayı ergenlerde incelenmesi. Yayınlanmamıs Yüksek Lisans Tezi, Marmara Üniversitesi Egitim Bilimleri Enstitüsü, İstanbul.

Erdik, C ve Özpınar, S. (2015). Üniversite sınavına girecek olan öğrencilerde anne baba tutumu ve sınav kaygisı ilişkisi. UCED Uluslararası Ail eve Çocuk Eğitim Dergisi, 7, 158-172.

Ergene, T. (2011). The relationships among test anxiety, study habits, achievement, motivation, and academic performance among turkish high school students. Education and Science, 36(160), 321-330.

Erkan, S. (1991). Sınav kaygısının öğrenci seçme sınavı ile ilişkisi. Yayınlanmamis Doktora Tezi. Ankara Universitesi, Sosyal Bilimler Enstitüsü, Ankara.

Freud, S. (1998). Ruh çözümlemesine yeni giriş konferanslar. (E. K. Kapkın, Çev.) İstanbul: Payel Yayınevi.

Freud, S. (1999). Psikopatoloji. (H. Atalay, Çev.) İstanbul: Payel Yayınevi.

Freud, S. (2012). Düşlerin yorumu I. (E. Kapkın, Çev.) İstanbul: Payel Yayınevi.

Gençdoğan, B. (2006). Lise öğrencilerinin sınav kaygısı ile boyuneğicilik düzeyleri ve sosyal destek algısı arasındaki ilişkiler. Atatürk Üniversitesi Sosyal Bilimler Dergisi, 7(1), 153-164.

Güler, D. Ve Çakır, G. (2013). Lise son sınıf öğrencilerinin sınav kaygısını yordayan değişkenlerin incelenmesi. Türk Psikolojik Danışma ve Rehberlik Dergisi, 4(39), 82-94.

Gündoğdu, M. (1994) The relationship between helpless explanatory style, test anxiety and academic achievement among sixth grade basic education students. Yayınlanmamış yüksek lisans tezi. ODTÜ, Ankara.

Hambree, R. (1988). Correlates, causes, effects and treatment of test anxiety. Review of Educational Research, 58(1), 47-77.

Hanımoğlu, E. (2011). Seviye sınavına girecek olan ilköğretim ikinci kademe öğrencilerinde sınav kaygısı mükemmeliyetçilik ve annebaba tutumu arasındaki ilişkinin incelenmesi. Çukurova Üniversitesi Sosyal Bilimler Enstitüsü Dergisi, 20(1), 351-366. 
Harris, T. A. (2012). Ben Ok'im - Sen Ok'sin. (M. Şahin, Dü., \& H. U. Nilgün Sağlam, Çev.) İstanbul: Okuyan Us.

Hay, J. (2015). Eğitmenler için transaksiyonel analiz. (O. S. Dalkılıç, Çev.) Ankara: Nobel Akademik Yayıncılık Eğitim Danışmanlık.

Hong, E. (1999). Test anxiety, percieved test difficulty and test performance patterns of their effects. Learning EIndividual Differences, 11, 431-447.

https://www.yeniakit.com.tr/haber/ulkemizde-universite-sinav-sisteminin-tarihi-385408.html. Erişim tarihi: 28 Nisan 2019.

Kavakçı, Ö., Güler, A. S. ve Çetinkaya, S. (2011). Sınav kaygısı ile ilişkili psikiyatrik belirtiler. Klinik Psikiyatri Dergisi, 14, 7-16.

Kekler, H. (2008). Liseli ergenlerin transaksiyonel analiz ego durumlar ile bağlanma stilleri arasındaki ilişkinin incelenmesi. Yayımlanmamış Yüksek Lisans Tezi, Marmara Üniversitesi Eğitim Bilimleri Enstitüsü, İstanbul.

Koçkar, A. İ., Kılıç, B. G., ve Şener, Ş. (2002). ilköğretim öğrencilerinde s1nav kaygısı ve akademik başarı. Çocuk ve Gençlik Ruh Sağhığı Dergisi, 2, 100- 105.

Koruklu (Öner) N., Öner, H. ve Oktaylar H.C. (2006). “Sınav kaygısı ile başa çıkma programının" sınav kaygısına etkisine yönelik deneysel bir çalışma. Dokuz Eylül Üniversitesi Buca Ĕ̆itim Fakültesi Dergisi, 19, 5-11.

Kutlu, Ö. (2001). Adolescent anxiety caused by university entrance examinations. Education and Science, 26(121), 12-23.

May, R. (2012). Varoluşun keşfi. İstanbul: Okuyan Us.

Morris, L.W., Davis. M. A., and Hutchings, C. H. (1981). Cognitive and emotional component of anxiety: Literature review and a Resived Worry-Emotionalty Scale. Journal of Education Pyschology,73, 541555.

Neuderth, S., Jabs, B. And Schmidtke, A. (2009). Strategies for reducing test anxiety and optimizing exam preparation in German University Student: A Prevention-oriented pilot projecet of the unuversity of Würzburg. Journal of Neural Transm., 116, 785-790.

Öner, N. (1990). Sinav kaygısı envanteri el kitabı. İstanbul: Yükseköğretimde Rehberliği Tanıtma ve Rehber Yetiştirme Vakfı Yayını. 
Öner, N. v. (1985). Durumluluk-sürekli kaygı envanteri el kitabı. İstanbul: Boğaziçi Üniversitesi Yayınları.

Özerk, H. (2008). Özel okul yöneticilerinin ve öğretmenlerinin, transaksiyonel analiz kuramı çerçevesinde, birbirlerinde gözlemledikleri ve birbirlerinde bekledikleri ego durumları'nın karşılaştırılması. Yayımlanmamış Yüksek Lisans Tezi, Yeditepe Üniversitesi Sosyal Bilimler Enstitüsü, İstanbul.

Öztürk, A. U. (2011). Ruh sağhlğ̆ı ve bozuklukları (11.Baskı b., Cilt I). Ankara: Nobel Tip Kitapevleri.

Sacks, O. (2014). Karısını şapka sanan adam. (Ç. Çalkılıç, Çev.) İstanbul: Yapı Kredi Yayınları.

Sarason I.G (1980). Introduction to the study of test anxiety. Test Anxiety: Theory, research, and applications. I.G. Sarason (Ed.). (Vol.1) Hillsdale, New Jersey: Lawrence Erlbaum Associates Inc., Publishers.

Sud, A., ve Parabha, 1. (1995). Test anxiety and academic performance: Cognitive/relaxation therapies. Pyschological Studies, 40, 179-186.

Sullivan, L. (2002). The effect of test anxiety on attention and memory skills in undergraduate students. Chrestomatly: Annual Review of Undergraduate researchat the College of Cherleston, 1, 263-273.

Yıldırım, İ. (2008). Üniversite giriş sınavına hazırlanan öğrencilerde sınav kaygısını etkileyen ailesel değişkenler. Eurasian Journal of Educaional Research, 31, 171-186.

Yıldırım, İ., Ergene T. (2003). Lise son sınıf öğrencilerinin akademik başarılarının yordayıcısı olarak sınav kaygısı, boyun eğici davranışlar ve sosyal destek. Hacettepe Üniversitesi Eğitim Fakültesi Dergisi, 25, 224-234.

Yıldız, H. (2007). Sınav kaygısı ana- baba tutumları ve mükemmeliyetçilik arasındaki ilişkinin incelenmesi. Yayımlanmamış Yüksek Lisans Tezi, Gazi Üniversitesi Eğitim Bilimleri Enstitüsü, Ankara.

Zeidner, M. (1991). Statistics and mathematics anxiety in social science students: Some interesting parallels. British Journal Of Educational Psychology, 61(3), 319-328 


\section{Kaynakça Bilgisi / Citation Information}

Meşe, S. Ş. ve Özerk, H. (2019). Üniversite sınavına hazırlanan ve özel dershanelere devam eden lise son sinıf öğrencilerinin kendilerinde algıladıkları ego durumları ile sınav kaygı düzeyleri arasındaki ilişkinin incelenmesi. OPUS-Uluslararası Toplum Araştırmaları Dergisi, 11(18), 727-756. DOI: 10.26466/opus.522188 